Proc. Estonian Acad. Sci. Biol. Ecol., 2004, 53, 4, 260-268

\title{
Distribution and dynamics of drifting macroalgal mats in Estonian coastal waters during 1995-2003
}

\author{
Tiina Paalme ${ }^{\mathrm{a}, \mathrm{b}^{*}}$, Georg Martin ${ }^{\mathrm{a}}$, Jonne Kotta ${ }^{\mathrm{a}}$, Henn Kukk ${ }^{\mathrm{a}, \mathrm{b}}$, \\ and Kaire Kaljurand ${ }^{\mathrm{a}, \mathrm{b}}$ \\ ${ }^{a}$ Estonian Marine Institute, University of Tartu, Mäealuse 10a, 12618 Tallinn, Estonia \\ ${ }^{\mathrm{b}}$ Faculty of Mathematics and Natural Sciences, Tallinn Pedagogical University, Narva mnt. 25, \\ 10120 Tallinn, Estonia
}

Received 17 March 2004, in revised form 25 August 2004

\begin{abstract}
The occurrence of drifting algal mats has become a widespread phenomenon in shallow coastal waters of the Baltic Sea. In Estonian coastal waters the drifting algal mats were found on sandy-clayey bottoms in relatively shallow and sheltered bays. Except for a few localities of the Gulf of Finland, Pilayella littoralis or Ectocarpus siliculosus prevailed in the drifting algal mats. The abundance of invertebrate feeding types (herbivores or detrivores) was related to the physiological state of the macroalgae in the mat.
\end{abstract}

Key words: Cladophora glomerata, detrivores, drifting macroalgal mats, Estonian coastal waters, herbivores, Ihasalu Bay, Kõiguste Bay, Pilayella littoralis, spatial distribution.

\section{INTRODUCTION}

Within the past few decades the extensive supply of nutrients into coastal ecosystems has resulted in the luxurious growth of filamentous macroalgal species in many regions of the world. As a consequence of large macroalgal "blooms", the mass drift of algae is increasingly observed. This is due to the detachment of sessile filamentous algae at the end of their lifecycles and/or disturbances, caused by heavy wave actions or currents. The algae are either washed up on the shore or they sink down and form drifting algal mats on the sea bottom (Morand \& Briand, 1996; Paerl, 1997; Valiela et al., 1997).

\footnotetext{
* Corresponding author, tiina.paalme@ut.ee
} 
The occurrence of drifting algal mats has become a widespread phenomenon also in shallow coastal waters of the Baltic Sea (Kiirikki \& Blomster, 1996; Norkko \& Bonsdorff, 1996a,b; Bäck et al., 1996, 2000; Vahteri et al., 2000; Lehvo \& Bäck, 2001). The proliferation of annual filamentous algae and the formation of drifting algal mats has been observed in the whole Estonian coastal range (Trei, 1983, 1991; Martin et al., 2003). It is suggested that the occurrence of drifting algal mats reflects the shift in macroalgal communities from the perennial macrophytes to fast growing filamentous macroalgae, caused by increasing eutrophication of coastal waters in the Baltic Sea during the past decades (Nehring \& Matthäus, 1987; Rosenberg et al., 1990; Bäck et al, 1993; Mäkinen et al, 1994; Bonsdorff et al., 1997). Naturally Baltic filamentous algae grow on different hard substrates and exhibit strong seasonality (Kiirikki, 1996; Kiirikki \& Lehvo, 1997). However, after detachment and formation of loose lying algal mats, they may extend their growing area to a completely new niche, to soft bottoms. Occupying a unique habitat of higher aquatic plant and macrozoobenthos communities, the drifting algal mats represent a serious threat to the biodiversity of coastal areas (Lehvo \& Bäck, 2001). The accumulation and decomposition of these algal mats can modify nutrient dynamics both in a water column and sediment (Lavery \& McComb, 1991; Peckol \& Rivers, 1996; Paalme et al., 2002), affect negatively the underwater light climate, result in widespread hypoxic and anoxic conditions among the algae and in the sediment, and hence destabilize the whole shallow-water ecosystem (Norkko \& Bonsdorff, 1996a,b; Hansen \& Kristensen, 1997).

Although the drifting macroalgal mats are a very important part of the productivity and functioning of the shallow coastal areas of the Baltic Sea, there are only a few papers dealing with various aspects of their development and occurrence (Bäck et al., 2000; Vahteri et al., 2000; Lehvo \& Bäck, 2001; Paalme et al., 2002; Salovius \& Bonsdorff, 2004). The aim of the study was to summarize all available records about the occurrence of the drifting macroalgal mats in Estonian coastal area in the last decade. The formation and development of drift algae were studied at two selected sites during one growing season.

\section{MATERIALS AND METHODS}

Since 1995 quantitative data on the spatial distribution of macroalgal communities have been regularly collected in Estonian coastal waters. During sampling the diver recorded the presence and spatial coverage of different macroalgal communities including the drift algal mats. Most of the studies were performed in late July and August. However, as the drift algae were not specially surveyed no quantitative frame samples from the mat were taken. In order to collect more quantitative information on the algal mats the development of the drifting algal mats was followed at two selected sites in the Gulf of Finland and the Gulf of Riga during the ice-free season in 2002/2003. In addition to plant species the 
biomass of associated invertebrates was estimated in the samples of the two selected sites. The samples of drifting macroalgal mats were collected by SCUBA diving. A frame sampler $\left(400 \mathrm{~cm}^{2}\right)$ was used both for plant and animal species. Dry weights were obtained after drying the plant material for 2 weeks and animals for $48 \mathrm{~h}$ at $60^{\circ} \mathrm{C}$.

The physiological state of the algal material during different developmental stages of the drifting algal mat was estimated in the two selected sites. For this purpose the net photosynthetic and dark respiration rates were measured using the oxygen method (Paalme et al., 2002).

\section{RESULTS}

The drifting macroalgal mats were observed at 18 localities throughout the Estonian coastline (Fig. 1). The drift algae were mainly found on sandy-clayey bottoms. The depth ranged from 0.5 to $12 \mathrm{~m}$, with the optimum values below 2-3 m (Table 1). Pilayella littoralis or Ectocarpus siliculosus were the prevailing macroalgal species that formed the algal mats. Monotypic mats that consisted mainly of Cladophora glomerata were observed only at two locations (Table 1).

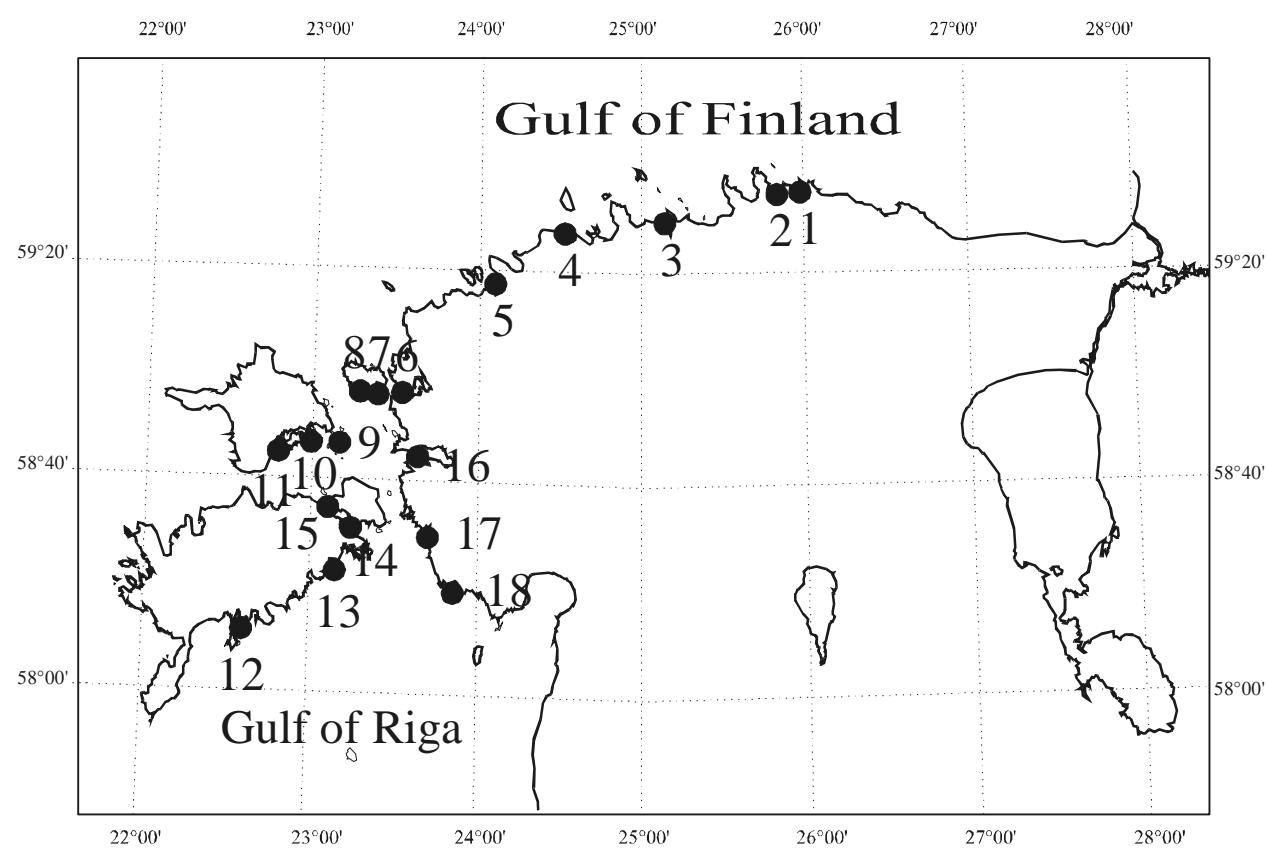

Fig. 1. Study area. Filled circles indicate the sites where drifting macroalgal mats were observed. Numbers refer to the locations listed in Table 1. 
Table 1. Locations where drifting macroalgal mats were observed together with depth range, dominant algal species, and prevailing bottom type

\begin{tabular}{|c|c|c|c|c|}
\hline No. & Location & $\begin{array}{c}\text { Depth range, } \\
\text { m }\end{array}$ & Dominant species & $\begin{array}{c}\text { Bottom } \\
\text { type }\end{array}$ \\
\hline 1 & Käsmu Bay * & $2-3$ & C. glomerata & Sand \\
\hline 2 & Eru Bay * & $4-8$ & C. glomerata & Sand \\
\hline 3 & Ihasalu Bay ** & $2-3$ & P. littoralis & Sand \\
\hline 4 & Kakumäe Bay ** & $1.5-3$ & P. littoralis & Sand \\
\hline 5 & Pakri Bay* & $1-2$ & P. littoralis and/or C. glomerata & Sand \\
\hline 6 & Haapsalu Bay *** & $0.5-2$ & P. littorali or E. siliculosus & Sand, clay \\
\hline 7 & Sviby Bay $* * *$ & $0.5-1.5$ & P. littoralis or E. siliculosus & Sand, clay \\
\hline 8 & Hullo Bay *** & $0.5-2$ & P. littoralis or E. siliculosus & Sand, clay \\
\hline 9 & Heinlaid $* *$ & $1-4$ & $\begin{array}{l}\text { P. littoralis or E. siliculosus } \\
\text { and/or C. glomerata }\end{array}$ & Sand, clay \\
\hline 10 & Õunaku Bay $* *$ & $1-2$ & P. littoralis or E. siliculosus & Sand, clay \\
\hline 11 & Jausa Bay ** & $1-2$ & P. littoralis or E. siliculosus & Sand, clay \\
\hline 12 & Kuressaare Bay * & $1-2$ & P. littoralis or E. siliculosus & Sand, clay \\
\hline 13 & Kõiguste Bay $* * *$ & $0.5-1,3-5,8-12$ & P. littoralis or E. siliculosus & Sand, clay \\
\hline 14 & Väike väin * & $1.5-2$ & P. littoralis or E. siliculosus & Sand \\
\hline 15 & Väike väin * & $1.5-3$ & P. littoralis or E. siliculosus & Sand \\
\hline 16 & Matsalu Bay *** & $2-3$ & P. littoralis or E. siliculosus & Sand, clay \\
\hline 17 & Paatsalu Bay ** & $0.5-2$ & P. littoralis or E. siliculosus & Sand \\
\hline 18 & Tõstamaa Bay ** & $0.5-1$ & P. littoralis or E. siliculosus & Sand \\
\hline
\end{tabular}

\footnotetext{
* Macroalgal mats were found during a single observation.

** Macroalgal mats were found occasionally.

*** Macroalgal mats were found during every observation.
}

In Ihasalu Bay (3 in Fig. 1) drift algae were first observed in early June at 1.5 to $2 \mathrm{~m}$ depth. The patches were small and elongated and their shape followed the patterns of sand waves. The size of the patches was less than $0.5 \mathrm{~m}^{2}$ and the thickness about $5 \mathrm{~cm}$. Ten days later the size of the patches had increased approximately up to $20-30 \mathrm{~m}^{2}$. The thickness of the mat varied between 5 (in June) and 9 (in July) $\mathrm{cm}$. The average biomass of the algae was in the range 70 to $280 \mathrm{~g} \mathrm{dw} \mathrm{m}^{-2}$ (Fig. 2a). Drift algae covered less than $10 \%$ of the total bottom area of the bay. The dominant macroalgal species was $P$. littoralis. In June up to $97-99 \%$ of the total biomass consisted of $P$. littoralis, but in July the proportion of $C$. glomerata had increased on average to $15 \%$ (Fig. $2 b$ ). The biomass of other species (the phanerogams Ruppia sp. and Zostera marina, the green alga Enteromorpha intestinalis, the red algae Ceramium tenuicorne and Polysiphonia fucoides) was less than $1 \%$ of the total biomass of the mat. 
(a)

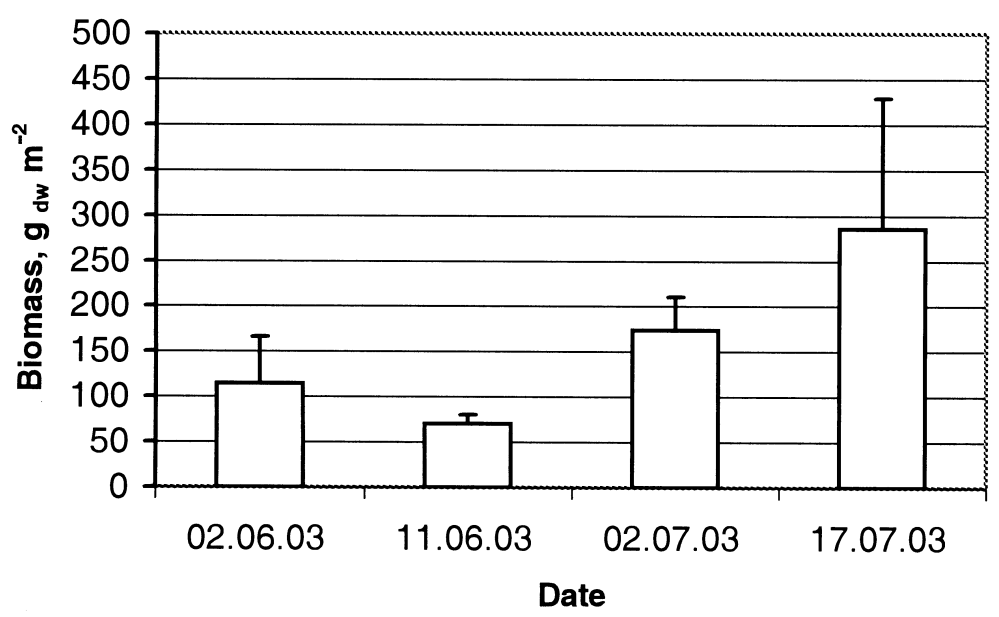

(b)

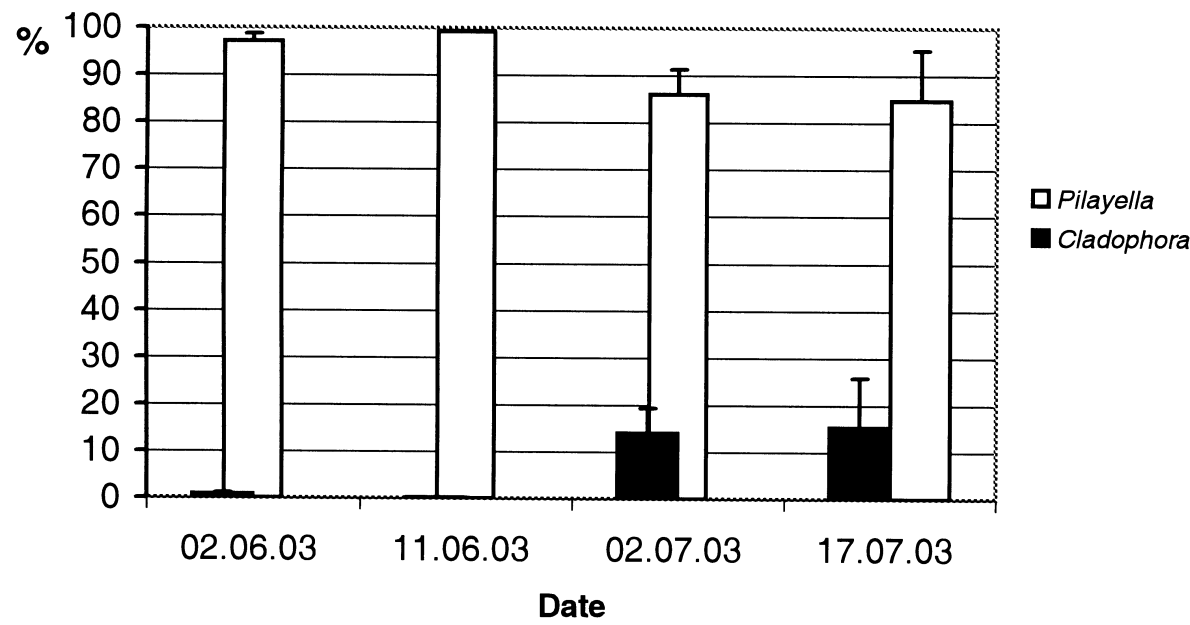

Fig. 2. Total biomass of the drifting macroalgal mat (a) and the percentage of Pilayella littoralis and Cladophora glomerata in the total biomass of the mat (b) $( \pm \mathrm{SE}, n=3)$.

Patchy occurrence of the algal mats was observed until their disappearance in the middle of July, when large amounts of decaying algal mass were deposited on the shore. From August to early October high amounts of loose P. littoralis (ca 25\%) and C. glomerata (ca 75\%) occurred in the water column down to $3 \mathrm{~m}$ depth, but no formation of new algal mats was observed.

We found 9 zoobenthos taxa inside the macroalgal mat: Corixa sp., Lymnea sp., Bithynia tentaculata, Hediste diversicolor, Gammarus sp., Cerastoderma glaucum, 
Hironomidae, Theodoxus fluviatilis, and Physa fontinalis. Herbivores were the most important feeding type in terms of abundance and biomass. Nevertheless, the biomass of invertebrates was low and usually did not exceed $25 \mathrm{~g} \mathrm{dw} \mathrm{m}^{-2}$.

In June the drifting mats were productive, i.e. the net photosynthetic rates of $P$. littoralis measured were relatively high, up to $10 \mathrm{mgO}_{2} \mathrm{~g}_{\text {dry weight }} \mathrm{h}^{-1}$. In July the net photosynthetic rates of the mat decreased about 10 times, and the oxygen consumption rates (dark respiration) of the dominant species in algal mats increased.

In Kõiguste Bay drift algae were first observed in late May. About $25 \%$ of the total bottom area of the bay was covered by drift algae. The mat consisted mainly of $P$. littoralis, and the prevailing invertebrate species were the herbivores Hydrobia ulvae and Theodoxus fluviatilis. As the thickness of the mat rarely exceeded $1 \mathrm{~cm}\left(<20 \mathrm{~g} \mathrm{dw} \mathrm{m}^{-2}\right)$ the biomass of invertebrates did not exceed $20 \mathrm{~g} \mathrm{dw} \mathrm{m}^{-2}$. In July the average biomass of the drifting macroalgal mat was $330 \pm 154 \mathrm{~g} \mathrm{dw} \mathrm{m}^{-2}$. The mat was thickest and uniform at 4-5 $\mathrm{m}$ depth. The mat was not productive (i.e. photosynthetically not active). The prevailing species was $P$. littoralis. The thickness of the mat varied between 1 and $5 \mathrm{~cm}$. The most common animal species inside the mat was Macoma balthica. Consequently, detrivores were the dominant feeding group with average abundance of 1306 ind $\mathrm{m}^{-2}$ and average biomass of $76 \mathrm{~g} \mathrm{dw} \mathrm{m}^{-2}$. Hydrobia ulvae was the prevailing herbivore species inside the algal mat (Table 2). In early August the mat was almost decomposed and inhabited only by Chironomidae. Similarly to Ihasalu Bay the drift algae were partly productive in early summer and only decomposition took place in July-August.

Table 2. List of animal species found inside the drifting macroalgal mat in Kõiguste Bay in 2002

$\begin{array}{ll}\text { Polychaeta } & \text { Hediste diversicolor (Müller) } \\ & \text { Marenzelleria viridis (Verrill) } \\ \text { Nemertina } & \text { Prostoma obscurum Schultze } \\ \text { Crustacea } & \text { Saduria entomon (L.) } \\ & \text { Idotea baltica } \text { (Pallas) } \\ & \text { Jaera albifrons Leach } \\ & \text { Corophium volutator (Pallas) } \\ & \text { Gammarus oceanicus Segestråle } \\ & \text { Gammarus salinus Spooner } \\ \text { Gammarus juv. } \\ \text { Insecta } & \text { Chironomidae } \\ \text { Mollusca } & \text { Theodoxus fluviatilis (L.) } \\ & \text { Lymnaea sp. } \\ & \text { Hydrobia ulvae (Pennant) } \\ & \text { Hydrobia ventrosa (Montagu) } \\ & \text { Mytilus edulis } \text { L. } \\ & \text { Cerastoderma glaucum (Bruguire) } \\ & \text { Macoma balthica (L.) } \\ \text { Mya arenaria L. }\end{array}$




\section{DISCUSSION}

In Estonian coastal waters drifting macroalgal mats occurred as a rule on sandy-clayey bottoms. Normally filamentous algae do not grow on soft substrates. Hence, the mats represent a serious threat to phanerogams, Chara spp., and various animal species characteristic of soft sediments. The negative effects of drift algae include shading, increase in organic matter as a result of their degradation, and the development of anoxic conditions under the mats (Bonsdorff et al., 1997; Bäck et al., 2000; Vahteri et al., 2000; Lehvo \& Bäck, 2001).

Drifting macroalgal mats were found in rather small, shallow and sheltered bays (e.g. the Väinameri region in the Gulf of Riga). The mats were not found at open shores (e.g. at the western coasts of Saaremaa and Hiiumaa islands including Küdema Bay in the NW coast of Saarema Island).

Except for a few locations in the Gulf of Finland the prevailing species in drifting algal mats was $P$. littoralis or E. siliculosus. The next important species was $C$. glomerata. This pattern reflects the natural occurrence and dominance of species in the area. A similar species composition of drifting algal mats has been described in the Archipelago Sea area, SW Finland (Vahteri et al., 2000; Salovius $\&$ Bonsdorff, 2004) and in the northern coast of the Gulf of Finland (Lehvo \& Bäck, 2001).

Depending on the succession of dominant algal species as well as on meteorological conditions, drifting algal mats may occur during quite a short period or persist more than a year. The decomposition rate of a drifting algal mat depends on its species composition. The decomposition rate of $P$. littoralis is higher than of $C$. glomerata, especially in summer at high water temperatures (Paalme et al., 2002; Salovius \& Bonsdorff, 2004).

Most of drifting algal mats in the Estonian coastal zone were observed at very shallow depths and are thus strongly affected by wave action (storms). Occasionally mats are washed up to the shore before their complete decomposition (Golubkov et al., 2003). At greater depths with the more stable hydrodynamic conditions the drift algae persist longer and may even overwinter like in Kõiguste Bay in 2003.

Vahteri et al. (2000) described and classified drifting algal mass according to the thickness of the mat and occurrence of anoxia (smell of hydrogen sulphide, black coloured sediment). According to their classification the algal mats in the Estonian coastal area may be ranked as "algal cover", i.e. free floating productive algal mass or "mat" with visible oxygen deficiency in the lower layers. The "mattress", i.e. totally anoxic algal mass, was observed only at depths below $5 \mathrm{~m}$ in Kõiguste Bay.

The share of invertebrate feeding groups in macroalgal mats is probably dependent on the physiological state of the mat. In Ihasalu and Kõiguste bays in the case of productive "algal cover" the prevailing functional group inside the mat was herbivores, whereas detrivores were the most abundant functional group in the partly decomposed "algal mat". 
This study is a first attempt to summarize the data on the drift algae and associated invertebrates in the Estonian coastal sea. As the phenomenon has great ecological and socio-economic importance more detailed studies on the dynamics and environmental forcing of freefloating algal accumulations involving both field surveys and experimental manipulations are needed.

\section{ACKNOWLEDGEMENTS}

The present study was conducted under the framework of Estonian Governmental Programme No. 0182578s03 and with support from the Estonian Science Foundation grants Nos 5927, 5071, and 5103. Data from the Estonian National Marine Monitoring Programme were used together with results of other monitoring studies.

\section{REFERENCES}

Bäck, S., Mäkinen, A., Rissanen, J. \& Rönnberg, O. 1993. Phytobenthos monitoring: two case studies from the Finnish Baltic coast in summer 1993. Memorandum 1. Ministry of the Environment, Finland, 1-24.

Bäck, S., Kangas, P., Kukk, H., Martin, G. \& Viitasalo, I. 1996. Littoral changes in the Gulf of Finland: third periodic assessment of the state of the marine environment of the Baltic Sea, 1985-93. Baltic Sea Environ. Proc., 64B, 56-58.

Bäck, S., Lehvo, A. \& Blomster, J. 2000. Mass occurrence of the unattached Enteromorpha intestinalis on the Finnish Baltic coast. Ann. Bot. Fenn., 37, 155-161.

Bonsdorff, E., Blomqvist, E. A., Mattila, J. \& Norkko, A. 1997. Coastal eutrophication: causes, consequences and perspectives in the archipelago areas of the northern Baltic Sea. Estuarine Coastal Shelf Sci., 44, 63-72.

Golubkov, S. M., Alimov, A. F., Telesh, I. V., Anokhina, L. E., Maximov, A. A., Nikulina, V. N., Paveleva, E. B. \& Panov, V. E. 2003. Functional response of midsummer planktonic and benthic communities in the Neva Estuary (eastern Gulf of Finland) to anthropogenic stress. Oceanologia, 45, 53-66.

Hansen, K. \& Kristensen, E. 1997. Impact of macrofaunal recolonization on the benthic metabolism and nutrient fluxes in a shallow marine sediment previously overgrown with macroalgal mats. Estuarine Coastal Shelf Sci., 45, 613-662.

Kiirikki, M. 1996. Dynamics of macroalgal vegetation in the northern Baltic Sea - evaluating the effects of weather and eutrophication. Walter and Andree de Nottbecks Found. Sci. Rep., 12, 1-13.

Kiirikki, M. \& Blomster, J. 1996. Wind induced upwelling as a possible explanation for mass occurrence of epiphytic Ectocarpus siliculosus (Dillw.) Lyngb. (Phaeophyta) in the northern Baltic Proper. Mar. Biol., 127, 353-358.

Kiirikki, M. \& Lehvo, A.-M. 1997. Life strategies of filamentous algae in the northern Baltic Proper. Sarsia, 82, 259-267.

Lavery, P. S. \& McComb, A. J. 1991. Macroalgal-sediment nutrient interactions and their importance to macroalgal nutrition in a eutrophic estuary. Estuarine Coastal Shelf Sci., 32, 281-295.

Lehvo, A. \& Bäck, S. 2001. Survey of macroalgal mats in the Gulf of Finland, Baltic Sea. Aquat. Conserv. Mar. Freshwater Ecosyst., 11, 11-18.

Mäkinen, A., Hänninen, J, \& Vahteri, P. 1994. Underwater mapping of the biodiversity in the Archipelago Nature Conservation Park, SW Finland. Research report, Archipelago Research Institute of Turku University. 
Martin, G., Torn, K., Kotta, J. \& Orav-Kotta, H. 2003. Estonian marine phytobenthos monitoring programme: preliminary results and future perspectives. Proc. Estonian Acad. Sci. Biol. Ecol., 52, 112-124.

Morand, P. \& Briand, X. 1996. Excessive growth of macroalgae: a symptom of environmental disturbance. Bot. Mar., 39, 491-516.

Nehring, D. \& Matthäus, W. 1987. Current trends in hydrographic and chemical parameters and eutrophication in the Baltic Sea. Int. Rev. Gesamt. Hydrobiol., 76, 297-316.

Norkko, A. \& Bonsdorff, E. 1996a. Population responses of coastal zoobenthos to stress induced by drifting algal mats. Mar. Ecol. Prog. Ser., 140, 141-151.

Norkko, A. \& Bonsdorff, E. 1996b. Rapid zoobenthic community responses to accumulations of drifting algae. Mar. Ecol. Prog. Ser., 131, 143-157.

Paalme, T., Kukk, H., Kotta, J. \& Orav, H. 2002. "In vitro" and "in situ" decomposition of nuisance macroalgae Cladophora glomerata and Pilayella littoralis. Hydrobiologia, 475/476, 469-476.

Paerl, H. W. 1997. Coastal eutrophication and harmful algal blooms: importance of atmospheric deposition and groundwater as "new" nitrogen and other nutrient sources. Limnol. Oceanogr., 42, 1154-1165.

Peckol, P. \& Rivers, J. S. 1996. Contribution by macroalgal mats to primary production of a shallow embayment under high and low nitrogen-loading rates. Estuarine Coastal Shelf Sci., 43, 311-325.

Rosenberg, R., Elmgren, R., Fleischer, S., Jonnson, P., Persson, G. \& Dahlin, H. 1990. Marine eutrophication case studies in Sweden. Ambio, 19, 102-108.

Salovius, S. \& Bonsdorff, E. 2004. Effects of depth, sediment and grazers on the degradation of drifting filamentous algae (Cladophora glomerata and Pilayella littoralis). J. Exp. Mar. Biol. Ecol., 298, 93-109.

Trei, T. 1983. The species composition of phytobenthos in some shallow bays of Western Estonia. Proc. Estonian Acad. Sci. Biol., 32, 245-253 (in Russian).

Trei, T. 1991. Taimed Läänemere põhjal. Valgus, Tallinn.

Vahteri, P., Mäkinen, A., Salovius, S. \& Vuorinen, S. 2000. Are drifting algal mats conquering the bottom of the Archipelago Sea, SW Finland? Ambio, 29, 338-343.

Valiela, I., McClelland, J., Hauxwell, J., Behr, P. J., Hersh, D. \& Foreman, K. 1997. Macroalgal blooms in shallow estuaries: controls and ecophysiological and ecosystem consequences. Limnol. Oceanogr., 42, 1105-1118.

\title{
Vabalt hõljuvate makrovetikamattide levik ja dünaamika Eesti rannikumeres (1995-2003)
}

\author{
Tiina Paalme, Georg Martin, Jonne Kotta, \\ Henn Kukk ja Kaire Kaljurand
}

Vabalt hõljuvate makrovetikamattide esinemine on laialt levinud ja üha kasvavat tähtsust omav nähtus Läänemere rannikuvetes. Eesti rannikumeres esinevad vabalt hõljuvad vetikamatid suhteliselt madalates ja varjulistes lahtedes ning valdavalt liiva-savipõhjadel. Vetikamatte moodustavad tavaliselt Pilayella littoralis/ Ectocarpus siliculosus. Herbivooride ja detrivooride arvukus vetikamattides sõltub matis domineerivate vetikaliikide füsioloogilisest seisundist. 